\title{
Severity of Illness and Disability among Patients with Obsessive Compulsive Disorder: A Descriptive Cross Sectional Survey in a Tertiary Care Hospital in Northern India
}

\author{
Rakesh V.R ${ }^{1}$, Deepika Khakha ${ }^{2 *}$ and Nand Kumar ${ }^{3}$ \\ ${ }^{1}$ NIMHANS, Bangalore, Karnataka, India \\ ${ }^{2}$ College of Nursing, A.I.I.M.S, New Delhi, India \\ ${ }^{3}$ Department of Psychiatry, A.I.I.M.S, New Delhi, India
}

Received: October 6, 2016; Accepted: November 21, 2016; Published: November 24, 2016

*Corresponding author: Deepika Khakha, College of Nursing, A.I.I.M.S, New Delhi, India, Tel: +91-9810680818; E-mail: dckhakha@gmail.com

\begin{abstract}
Obsessive compulsive disorder is a chronic debilitating illness. A cross sectional study was undertaken on a sample of 80 patients in the outpatient clinic of Department of Psychiatry in a tertiary care hospital. The patients were assessed using Yale - Brown Obsessive Compulsive Scale (Y-BOCS) and World Health Organization Disability Assessment Schedule - 2 (WHO DAS -2), through a semi-structured interview. Majority of the patients under the study were having moderate to severe illness severity and high disability was seen in domains of Getting along, Participation, Work or school activities and Household activities in the disability assessment schedule. Positive correlation $(p=0.01)$ was found between domain scores of disability and severity of illness. High level of disability was associated with female gender $(p<0.05)$, earlier age of illness onset $(p<0.01)$, duration of treatment for less than one year $(p<0.05)$, less number of active care givers $(p<0.01)$ and irregular compliance with the treatment regimen $(p<0.05)$. The findings strongly suggest that Obsessive compulsive disorder is a chronic disabling illness and the Patient and care giver has to be taught about the nature of illness and the underlying pathology. They have to be taught relaxation exercises especially yoga, meditation, mindfulness training and other healthy coping mechanisms which include positive cognitive behavioural strategies and the need for treatment and proper follow ups.
\end{abstract}

Keywords: Obsessive compulsive disorder; Severity; Illness; Disability

\section{Abbreviations \\ OCD: Obsessive Compulsive Disorder}

\section{Introduction}

Obsessive Compulsive Disorder (OCD) is an intriguing and often debilitating syndrome characterized by the presence of two distinct phenomena, obsessions and compulsions. It is a chronic psychiatric illness that affects from an approximate prevalence of $2 \%$ among the general population [1] and $0.6 \%$ among Indian population [2]. The disorder is equally common in both men and women and the onset is in childhood or early adult life; and often appears earlier in males [3]. The individuals presenting with OCD show a range of insight [4] and usually have co-morbid psychiatric disorders, with the most common being major depression [5].

The disorder is characterized by persistent, intrusive thoughts (Obsessions), and repetitive intentional behaviours (Compulsions). OCD is a heterogeneous disorder, where obsessional themes include contamination fears, pathological doubt, a need for symmetry or order, somatic obsessions and sexual or aggressive obsessions.

Studies [6,7] have consistently reported that the severity of OCD is related to functional impairment; however the characteristics of individuals who were unable to maintain employment is not well documented. Some researchers have suggested that variables such as duration of OCD, symptom severity and severity of co-morbid psychiatric conditions may be associated with occupational disability [8]. A few studies have also stated that OCD is often connected with marital discord [9] problems in sexual relationships [10] financial constraints, restricted leisure and poor family relationships [11].

The World Health Organization has determined that mental illness is one of the largest contributors to disability worldwide $[12,13]$.

There is dearth of literature available regarding in the Indian setting about the functional impairment and disability among patients with Obsessive Compulsive Disorder.

\section{Aim}

To explore the level of disability with regard to the symptom severity and other disease specific variables among Obsessive compulsive disorder patients

The research questions were

- What is the severity of illness among patients having OCD? 
- What is the level of disability among patients having OCD?

- Is there any association between level of disability and variables like sex, educational status, age of illness onset, occupational status?

\section{Method}

\section{Design}

A descriptive cross sectional design.

\section{Sample}

Sample is comprised of Adult patients seeking treatment/ follow-up from the selected setting who were diagnosed with Obsessive Compulsive Disorder as per ICD-10 criteria by the treating psychiatrist. The inclusion criteria was patients who are diagnosed as OCD for at least 6 months duration, age between 18 yrs to 60 yrs and who were able to understand Hindi or English. The exclusion criteria was patients with any other co- morbid psychiatric illness especially major depression (Screened by using Hamilton Rating scale for Depression or HAM -D) and substance use disorders, patients who had any co-morbid debilitating chronic medical-surgical illness. The total sample screened was 136 , among that 6 refused consent, 30 had moderate depression and 20 were having substance use disorder and the final sample enrolled in study after screening was 80 subjects.

\section{Data collection}

Data was collected from the patients during the period of May 2013 until December 2013.

\section{Tools}

The researcher used three tools for data collection, which includes questionnaire for demographic details (Data sheet), tool for assessing severity of illness (Y- BOCS) and tool for assessing disability (WHO DAS-II).

Data sheet was a semi structured questionnaire of 22 items, developed by the researcher, organized in two sections. First section was the demographic profile of the patient. The section II of data sheet contains selected variables like staying with whom, type of symptoms, duration of illness, compliance with the treatment, age of onset of illness, duration of treatment, type of onset, course of illness, frequency of follow ups, distance from hospital and number of care givers in family etc.

Yale Brown Obsessive Compulsive Scale (Y-BOCS) [14] is a rater-administered 10 item scale with specific probes and anchors that assesses severity of 5 domains for obsessions and compulsions. These domains include time spend, distress, interference, resistance, and control. The scoring of each domain varies from 0 to 4 . The patients were asked to think over the past one week time and have to reveal the average occurrence of each item on the scale during the prior week up to and including the time of interview. The scores obtained will give a total picture of the obsessive compulsive symptoms over a period of time.

The WHO Disability Assessment Schedule (WHO DAS-II) [15] was a standardized interview tool developed by World Health
Organization. The 36 item, interviewer administered version was used which allows patient to provide his/her evaluation of difficulties with functioning. The 36 items in the tool were categorized into following six domains. i.e. cognition, mobility, self care, getting along, life activities (separate sections for household and work or school activities) and participation. The internal consistency reliability coefficient was $r=0.90$. The Approximate time for completion of all items in this part was 10 minutes.

The reliability of tools was established through test - retest method; that includes Yale Brown Obsessive Compulsive Scale (Cronbach's alpha $=0.80$ ) and WHO DAS II, 36 item version (Cronbach's alpha $=0.90$ ). Tool No. 1: Y - BOCS and tool No. 2: WHO DAS II were translated to Hindi by the language experts from the institute and was back translated to English to ensure that original meaning was not lost during translation.

\section{Tryout of Tools}

All the Hindi and English tools were tried out on ten subjects prior to use. All the tools were found to be appropriate for population under study.

\section{Ethical approval}

Approval to conduct the study was obtained from the Institute ethics committee. Written permission was taken from respective authors to use the standardized tools (Tool No.1: Y- BOCS and Tool No.2: WHO DAS II) for this study.

\section{Procedure}

All patients diagnosed as Obsessive compulsive disorder by the consultant psychiatrist and senior residents of the outpatient Department of Psychiatry as per ICD-10 criteria were referred to the investigator. The referred patients who fulfilled the inclusion criteria were explained the purpose of study and enrolled into study after taking informed written consent. The tools were administered to the patients. Approximate time taken was 30 minutes for each participant.

\section{Statistical analysis}

Data were analyzed by using statistical package SPSS 17.0 version. Descriptive statistic i.e, mean, median, percentage, range, standard deviation and inferential statistics i.e, Mann Whitney U test, Kruskal Wallis test and Spearman's correlation test were used for analysis of data. The level of significance was set as $p<0.05$

\section{Results}

\section{Patient's socioeconomic details}

The mean age of patients was $28 \pm 6.35$ years. $58.8 \%$ of the patients were male. Majority $(61.3 \%)$ of the patients were unmarried. The most common obsession reported by the patients was contamination $(71.3 \%)$, and the common compulsion was washing (71.3\%). Majority were having insidious onset of illness $(93.8 \%)$ and continuous course of illness (91.3\%). The other details are given in the tables. 


\section{Severity of illness}

In study subjects the mean total severity scores for obsessions and compulsions were $22.45 \pm 5.67$, (95\% CI $21.25-23.74)$ (Score ranges from $0-40$ ). Nearly half $(45 \%)$ of the patients were having moderate severity of illness (Total severity score between 16 and 23), about one by third (37.5\%) of the patients having severity of illness in severe range (Total severity score between 24 and 31).

\section{Level of disability}

The disability scores of patients are shown in table No. 4. The results reveal that the patients with Obsessive compulsive disorder experiences significant disability particularly in Domains of Getting along, Participation and life activities. Patients were found to experience complete inability to work ('work loss days') for a mean duration of $8.99 \pm 5.36$ days in a month and restriction in work ('work cut back days') for a mean duration of $10.56 \pm 5.22$ days in a month.

\section{Correlation between severity of illness and disability}

In present study significant positive correlation was found between disability score of patients in all domains and obsession severity (Spearman's correlation test, $p=0.001$ ), compulsion severity (Spearman's correlation test, $p=0.001$ ) and the total severity scores (Spearman's correlation test, $p=0.001$ ).

\section{Association between level of disability and selected variables}

In present study, it was found that females were having high disability compared to males in domains of mobility ( $p=$ $0.004)$, self care $(p=0.001)$, household activities $(p=0.030)$ and participation $(p=0.040)$. Also the disability was high in patients who were taking treatment for less than one year, as compared to those who were on treatment for more than one year in domains of cognition $(p=0.030)$ and mobility $(p=0.003)$. The disability in self care domain was high among patients who were having only two active care givers, compared to those having more than two active care givers $(p=0.005)$ which was significant. The patients who were taking follow up visits within two weeks were found to have high disability than those taking visits between two to four weeks and more than four weeks interval in domains of mobility $(p=0.047)$, self care $(p=0.036)$ and participation $(p=0.047)$. The disability in participation domain was high among subjects who were having irregular compliance with the treatment regimen, compared to those having regular compliance to treatment ( $p=$ 0.023, Mann Whitney U test).

\section{Discussion}

In the present study, nearly half (45\%) of the patients were having moderate severity of illness and about one by third (38\%) of the patients were having severity of illness in the severe range, which were in line with other studies, Besiroglu L, et al. [16] and Bobes J, et al. [17], those have reported moderate to severe illness severity among the treatment seeking OCD patients. Patients with Obsessive compulsive disorder had high mean scores of disability particularly in domains of Getting along (53.02 \pm
15.70), Participation (50.10 \pm 12.25$)$, Work or school activities $(47.50 \pm 35.76)$ and Household activities ( $47.25 \pm 16.76)$. These results were consistent with the findings of six previous studies [8,18-22] where high disability was reported in patients with Obsessive compulsive disorder especially in work and social activities.

In the study, patients with Obsessive compulsive disorder also reported significant impairments in Cognitive domain as assessed from the understanding and communication in the cognitive domain of WHO-DAS- 2 were in agreement with the studies [23-25] that reported decreased cognitive performance among obsessive compulsive disorder patients. Significant associations $(p<0.05)$ were found between the domain scores of disability and the severity categories of illness, except in Domain - 4 (Getting along). The greater mean scores of disability were found in the severe and extreme illness category. In the present study, strong positive correlation $(p<0.05)$ was found between the disability scores of patients and obsession severity, compulsion severity and the total severity score. These findings were in concordance with the studies [19,26-28] that reported the functional impairment is related to severity of obsessions and compulsions.

It is observed in the present study subjects that females were found to have high disability in domains of mobility ( $p=$ $0.004)$, self care $(p=0.001)$, household activities $(p=0.030)$ and participation $(p=0.040)$. These findings were in discordance with the studies of Mathis MA de, et al. [29] and Lochner C, et al. [30] which reported that males with obsessive compulsive disorder were likely to have earlier age of illness onset and more functional impairment. However a study from India by Khess CRJ, et al. [31] has reported greater obsessive compulsive symptomatology and higher impairments in household and occupational functioning among females. The reason for such result in the present study may be, women in Indian culture were likely to have more household responsibilities and societal imposed restrictions that would pile up the impairments due to illness and probably experiencing higher disability in these areas. The samples have been excluded by HAM-D for depression and so it does not seem that women are presenting major depression.

The study found that being single was associated with high disability in work or school activity domain $(p=0.001)$ than married. In a study by Vikas A, et al. [32], reported that married people experiencing significantly less occupational and overall disability than people living single and marriage has a protective effect on disability related to OCD. In the present study majority (63\%) of the patients were living single, especially males who have potentially high roles in occupational activities, needs to be independent and have to contribute for running the family despite of illness, might have experienced more disability.

The findings of present study reveal that duration of treatment had significant influence on level of disability and patients who were taking treatment for less than one year were having high disability than those who were on treatment for one to two year and on treatment for more than two years in domains of Cognition $(p=0.030)$, Mobility $(p=0.003)$ and Household activities $(p=$ 
Table 1: Patients sociodemographic details $(\mathrm{N}=80)$

\begin{tabular}{|c|c|c|}
\hline \multicolumn{2}{|c|}{ Demographic characteristics of patients } & Mean \pm SD \\
\hline \multicolumn{2}{|l|}{ Age in years } & $28 \pm 6.35$ \\
\hline & & Frequency (\%) \\
\hline \multirow[t]{2}{*}{ Gender } & Male & $47(58.8)$ \\
\hline & Female & $33(41.3)$ \\
\hline \multirow[t]{3}{*}{ Marital status } & Never married & $49(61.3)$ \\
\hline & Married & $30(37.5)$ \\
\hline & Separated & $1(1.3)$ \\
\hline \multirow[t]{3}{*}{ Religion } & Hindu & 75 (93.8) \\
\hline & Muslim & $4(5.0)$ \\
\hline & Christian & $1(1.3)$ \\
\hline \multirow[t]{2}{*}{ Place of residence } & Urban & $45(56.3)$ \\
\hline & Rural & $35(43.8)$ \\
\hline \multirow[t]{3}{*}{ Distance from the hospital } & $<50 \mathrm{~km}$ & $58(72.5)$ \\
\hline & $50-200 \mathrm{~km}$ & $18(22.5)$ \\
\hline & $>200 \mathrm{~km}$ & $4(5.0)$ \\
\hline \multirow[t]{5}{*}{ Employment status } & Paid work & $22(27.5)$ \\
\hline & Self employed & $6(7.5)$ \\
\hline & Student & $34(42.5)$ \\
\hline & House wife & $13(16.3)$ \\
\hline & Unemployed & $5(6.3)$ \\
\hline \multirow[t]{5}{*}{$\begin{array}{l}\text { Type of occupation } \\
\text { (Remunerated work ) }\end{array}$} & Professional & 7 (8.8) \\
\hline & Executive & $12(15.0)$ \\
\hline & Skilled worker & $1(1.3)$ \\
\hline & Unskilled worker & $2(2.5)$ \\
\hline & Business & $6(7.5)$ \\
\hline \multirow[t]{2}{*}{ Type of family } & Joint family & $29(36.3)$ \\
\hline & Nuclear family & $51(63.7)$ \\
\hline \multirow[t]{4}{*}{ Monthly income (In Rupees) } & $<10,000$ & $25(31.3)$ \\
\hline & $10,000-20,000$ & $47(58.8)$ \\
\hline & $20,000-50,000$ & $7(8.80)$ \\
\hline & $>50,000$ & $1(1.3)$ \\
\hline \multirow[t]{4}{*}{ Patient staying with } & Alone & $1(1.3)$ \\
\hline & Parents & $51(63.7)$ \\
\hline & Spouse/ children & 27 (33.8) \\
\hline & $\begin{array}{l}\text { Hostel/ sheltered } \\
\text { house }\end{array}$ & $1(1.3)$ \\
\hline \multirow[t]{2}{*}{ Number of care givers } & Up to 2 & $63(78.8)$ \\
\hline & $>2$ & 17 (21.3) \\
\hline \multirow[t]{5}{*}{ Educational status } & Below $10^{\text {th }}$ & $4(5.0)$ \\
\hline & Class $10^{\text {th }}$ & 7 (8.8) \\
\hline & Inter/ +2/ Diploma & $28(35.0)$ \\
\hline & Graduate & $39(48.8)$ \\
\hline & $\begin{array}{l}\text { Post graduate or } \\
\text { more }\end{array}$ & $2(2.5)$ \\
\hline
\end{tabular}

Table 2: Details of illness and symptoms $(\mathrm{N}=80)$

\begin{tabular}{|c|c|c|c|c|}
\hline \multicolumn{2}{|c|}{ Characteristics of symptoms } & \multirow{2}{*}{$\begin{array}{l}\text { Male } \\
\text { f (\%) } \\
26 \\
(32.5)\end{array}$} & \multirow{2}{*}{$\begin{array}{l}\text { Female } \\
\text { f (\%) } \\
31(38.7)\end{array}$} & \multirow{2}{*}{$\begin{array}{l}\text { Frequency } \\
\text { (\%) } \\
57(71.3)\end{array}$} \\
\hline Obsession types & Contamination & & & \\
\hline & $\begin{array}{l}\text { Pathological } \\
\text { doubt }\end{array}$ & $\begin{array}{l}31 \\
(38.7)\end{array}$ & $18(22.5)$ & 49 (61.3) \\
\hline & Symmetry & $\begin{array}{l}21 \\
(26.2)\end{array}$ & 7 (8.7) & $28(35.0)$ \\
\hline & Aggression & $\begin{array}{l}13 \\
(16.2)\end{array}$ & $1(1.2)$ & $14(17.5)$ \\
\hline & Sexual & $6(7.5)$ & $3(3.7)$ & $9(11.3)$ \\
\hline & Others & $5(6.2)$ & $1(1.2)$ & $6(7.5)$ \\
\hline & Somatic & $2(2.5)$ & $2(2.5)$ & $4(5.0)$ \\
\hline \multirow[t]{7}{*}{ Compulsion types } & Washing & $\begin{array}{l}26 \\
(32.5)\end{array}$ & 31 (38.7) & 57 (71.3) \\
\hline & Checking & $\begin{array}{l}31 \\
(38.7)\end{array}$ & 17 (21.2) & $48(60.0)$ \\
\hline & $\begin{array}{l}\text { Symmetry and } \\
\text { precision }\end{array}$ & $\begin{array}{l}19 \\
(23.7)\end{array}$ & $7(8.7)$ & $26(32.5)$ \\
\hline & $\begin{array}{l}\text { Need to ask or } \\
\text { confess }\end{array}$ & $\begin{array}{l}16 \\
(20.0)\end{array}$ & $1(1.2)$ & 17 (21.3) \\
\hline & Others & $\begin{array}{c}9 \\
(11.3)\end{array}$ & $1(1.2)$ & $10(12.5)$ \\
\hline & Counting & $6(7.5)$ & $1(1.2)$ & $7(8.8)$ \\
\hline & Hoarding & $2(2.5)$ & $2(2.5)$ & $4(5.0)$ \\
\hline \multicolumn{2}{|l|}{ Details of illness } & \multicolumn{3}{|c|}{ Frequency (\%) } \\
\hline \multirow[t]{3}{*}{$\begin{array}{l}\text { Age of onset of } \\
\text { illness ( In years) }\end{array}$} & $<18$ years & \multicolumn{3}{|c|}{$13(16.3)$} \\
\hline & $18-25$ years & \multicolumn{3}{|c|}{$52(65.0)$} \\
\hline & $>25$ years & \multicolumn{3}{|c|}{$15(18.8)$} \\
\hline \multirow[t]{3}{*}{$\begin{array}{l}\text { Type of onset of } \\
\text { illness }\end{array}$} & Acute & \multicolumn{3}{|c|}{$1(1.3)$} \\
\hline & Sub acute & \multicolumn{3}{|c|}{$4(5.0)$} \\
\hline & Insidious & \multicolumn{3}{|c|}{75 (93.8) } \\
\hline \multirow[t]{2}{*}{$\begin{array}{l}\text { Type of course of } \\
\text { illness }\end{array}$} & Continuous & \multicolumn{3}{|c|}{73 (91.3) } \\
\hline & Others & \multicolumn{3}{|c|}{$7(8.8)$} \\
\hline \multirow[t]{3}{*}{$\begin{array}{l}\text { Duration of illness } \\
\text { ( In years ) }\end{array}$} & $1 / 2-1$ year & \multicolumn{3}{|c|}{$6(7.5)$} \\
\hline & 1 - 2 years & \multicolumn{3}{|c|}{$12(15.0)$} \\
\hline & $>2$ years & \multicolumn{3}{|c|}{$62(77.5)$} \\
\hline \multirow[t]{3}{*}{$\begin{array}{l}\text { Duration of } \\
\text { treatment ( In } \\
\text { years ) }\end{array}$} & $<1$ year & \multicolumn{3}{|c|}{$21(26.3)$} \\
\hline & $1-2$ years & \multicolumn{3}{|c|}{$21(26.3)$} \\
\hline & $>2$ years & \multicolumn{3}{|c|}{$38(47.5)$} \\
\hline \multirow[t]{3}{*}{$\begin{array}{l}\text { Frequency of } \\
\text { hospital follow up } \\
\text { visiting ( In weeks ) }\end{array}$} & Within 2 weeks & \multicolumn{3}{|c|}{$30(37.5)$} \\
\hline & $\begin{array}{l}\text { Between } 2-4 \\
\text { weeks }\end{array}$ & \multicolumn{3}{|c|}{$41(51.2)$} \\
\hline & $\begin{array}{l}\text { More than } 4 \\
\text { weeks }\end{array}$ & $9(1$ & 1.3) & \\
\hline $\begin{array}{l}\text { Compliance with } \\
\text { treatment }\end{array}$ & Regular & $32(4$ & 10.0) & \\
\hline & Irregular & $48(6$ & 60.0) & \\
\hline
\end{tabular}


0.041). Earlier studies [33,34] have showed that OCD is a chronic illness and treatment benefits are usually delayed i.e, minimum $12-24$ weeks for effective symptom reduction. The reason for such findings in the present study may be due to, that the study setting was a tertiary care center catering to mental health needs of all people and more likely to receive patients having chronic mental illness, who might have tried ineffective health services from outside before reaching the study centre, and among them the treatment efforts takes time for the functional improvements to be evident.

The study reveals that patients who were having illness onset before eighteen years were having high disability than those with onset after eighteen years in work or school activity domain $(p=0.002)$. These findings were in line with Eisen JL, et al. [35] that reported earlier onset of illness is associated with decreased likelihood of remission and continued impairment. In the study patients who were having irregular compliance with treatment found to have higher disability than those with regular compliance in participation domain $(p=0.023)$. Earlier studies [36] have also reported lack of treatment compliance leading to ineffectiveness of treatment and further hampering functional outcome. However the present study did not elucidated the reason for noncompliance.

No association was found between level of disability of

Table 3: Scores of severity of illness ( $\mathrm{N}=80$ )

\begin{tabular}{|l|l|l|l|l|}
\hline \multirow{2}{*}{ Severity of illness } & \multicolumn{3}{l|}{ Scores of Severity of illness } & \multirow{2}{*}{$\mathbf{9 5}$ \% CI } \\
\cline { 2 - 5 } & Mean \pm SD & Median & Range & \\
\hline Obsessions & $11.89 \pm 2.97$ & 12.00 & $4-20$ & $11.22-12.55$ \\
\hline Compulsions & $10.56 \pm 3.03$ & 10.50 & $0-16$ & $9.93-11.26$ \\
\hline $\begin{array}{l}\text { Total obsessions and } \\
\text { compulsions }\end{array}$ & $22.45 \pm 5.67$ & 22.00 & $4-35$ & $21.25-23.74$ \\
\hline
\end{tabular}

patients and type of onset of illness and type of course of illness. The reason for such finding in this particular study may be due to the fact that more than ninety percent of the patients are having insidious onset of illness and continues course of illness.

\section{Limitations and Strengths}

As for the generalizability of the findings, some cautions must be acknowledged. There are some limitations like Single setting (Tertiary hospital, teaching hospital), the study was cross sectional in nature and those who were not coming for regular follow ups could not be included (Treatment resistant cases and those having non compliance to treatment). It is worthwhile to mention that hundred percentages of the patients were on SSRIs. The major strengths include; an ethical approval is obtained, good sample size and has used standardized tools for data collection.

\section{Conclusions and Implications}

The main conclusions drawn from the study includes

Nearly half $(45 \%)$ of the patients were having severity of illness in the moderate range and about $38 \%$ of patients are having severe illness. The level of disability of patients with Obsessive compulsive disorder was high particularly in domains of Getting along, Participation, Work or school activity and Household activities. Significant associations were found between severity categories of illness and domain scores of disability, except in Domain - 4 (Getting along). High positive correlation was found between the domain scores of disability and the severity of illness. High level of disability was associated with female gender, earlier age of illness onset, duration of treatment for less than one year, less number of active care givers, and irregular compliance with the treatment regimen.

Patient and care giver has to be taught about the nature of illness and the underlying pathology. They have to be taught relaxation exercises especially yoga, meditation, mindfulness

Table 4: Scores of disability $(\mathrm{N}=80)$

\begin{tabular}{|c|c|c|c|c|c|}
\hline \multirow{2}{*}{ Scores of disability } & \multicolumn{4}{|c|}{ Scores of Disability } & \multirow{2}{*}{$95 \%$ CI } \\
\hline & Mean \pm SD & Median & \multicolumn{2}{|l|}{ Range } & \\
\hline Domain - 1 (Cognition) & $43.63 \pm 15.19$ & 40.00 & \multicolumn{2}{|l|}{$0.00-95.00$} & $40.21-46.98$ \\
\hline Domain - 2 (Mobility) & $31.25 \pm 18.71$ & 31.25 & \multicolumn{2}{|l|}{$0.00-81.25$} & $27.13-35.46$ \\
\hline Domain - 3 (Self care) & $45.00 \pm 17.57$ & 50.00 & \multicolumn{2}{|c|}{$10.00-90.00$} & $41.08-48.91$ \\
\hline Domain - 4 (Getting along) & $53.02 \pm 15.70$ & 50.00 & \multicolumn{2}{|c|}{$8.33-91.66$} & $49.50-56.49$ \\
\hline Domain - 5 (1) (Household activities) & $47.25 \pm 16.76$ & 40.00 & \multicolumn{2}{|l|}{$0.00-90.00$} & $43.56-51.03$ \\
\hline Domain - 5 (2) (Work or school activities) & $47.50 \pm 35.76$ & 50.00 & \multicolumn{2}{|l|}{$0.00-100.0$} & $39.15-55.24$ \\
\hline Domain - 6 (Participation) & $50.10 \pm 12.25$ & 50.00 & \multicolumn{2}{|l|}{$4.16-79.16$} & $47.36-52.83$ \\
\hline $\begin{array}{l}\text { St } 32 \text { (Summary score of disability without remunerated work items) } \\
\text { items) }\end{array}$ & $44.93 \pm 12.52$ & 44.02 & \multicolumn{2}{|l|}{$3.26-81.52$} & $42.11-47.68$ \\
\hline St 36 (Summary score of disability with remunerated work items) & $45.27 \pm 13.35$ & 43.86 & \multicolumn{2}{|l|}{$2.83-83.01$} & $42.46-48.33$ \\
\hline \multicolumn{6}{|l|}{ Disability in terms of days unable to work } \\
\hline Number of days unable to work & Mean \pm SD & \multicolumn{2}{|l|}{ Median } & \multicolumn{2}{|l|}{ Range } \\
\hline Number of Work loss days (in days) & $8.99 \pm 5.36$ & \multicolumn{2}{|l|}{8.50} & \multicolumn{2}{|l|}{$0-30$} \\
\hline Number of Work cut back days (in days) & $10.56 \pm 5.22$ & \multicolumn{2}{|l|}{10.00} & \multicolumn{2}{|c|}{$0-20$} \\
\hline
\end{tabular}


Table 5: Correlation between Severity of illness among Patients with Obsessive Compulsive Disorder and their domain wise scores of Disability $(\mathrm{N}=80)$

\begin{tabular}{|c|c|c|c|c|}
\hline $\begin{array}{c}\text { Scores of Severity } \\
\text { of illness }\end{array}$ & \multirow{2}{*}{$\begin{array}{c}\Psi \\
\text { 'r' value } \\
\text { p value }\end{array}$} & \multirow{2}{*}{$\begin{array}{c}\text { Obsession } \\
\text { severity }\end{array}$} & \multirow{2}{*}{$\begin{array}{c}\text { Compulsion } \\
\text { severity }\end{array}$} & \multirow{2}{*}{$\begin{array}{c}\text { Total } \\
\text { severity }\end{array}$} \\
\hline $\begin{array}{l}\text { Domains of } \\
\text { Disability }\end{array}$ & & & & \\
\hline \multirow{2}{*}{$\begin{array}{l}\text { Domain - } 1 \\
\text { (Cognition) }\end{array}$} & $\mathrm{r}$ value & $0.412^{* *}$ & $0.562^{* *}$ & $0.519^{* *}$ \\
\hline & $\mathrm{p}$ value & 0.001 & 0.001 & 0.001 \\
\hline \multirow{2}{*}{$\begin{array}{l}\text { Domain - } 2 \\
\text { (Mobility) }\end{array}$} & rvalue & $0.402^{* *}$ & $0.370^{* *}$ & $0.428^{* *}$ \\
\hline & $\mathrm{p}$ value & 0.001 & 0.001 & 0.001 \\
\hline \multirow{2}{*}{$\begin{array}{l}\text { Domain - } 3 \\
\text { (Self care) }\end{array}$} & $\mathrm{r}$ value & $0.407^{* *}$ & $0.464^{* *}$ & $0.464^{* *}$ \\
\hline & $\mathrm{p}$ value & 0.001 & 0.001 & 0.001 \\
\hline \multirow{2}{*}{$\begin{array}{c}\text { Domain - } 4 \\
\text { (Getting along) }\end{array}$} & $\mathrm{r}$ value & $0.309^{* *}$ & $0.241 *$ & $0.295^{* *}$ \\
\hline & $\mathrm{p}$ value & 0.005 & 0.031 & 0.008 \\
\hline \multirow{2}{*}{$\begin{array}{c}\text { Domain - } 5(1) \\
\text { (Household } \\
\text { activities ) }\end{array}$} & r value & $0.477^{* *}$ & $0.442^{* *}$ & $0.484^{* *}$ \\
\hline & $\mathrm{p}$ value & 0.001 & 0.001 & 0.001 \\
\hline \multirow{2}{*}{$\begin{array}{l}\text { Domain - } 5(2) \\
\text { (Work or school } \\
\text { activities) }\end{array}$} & $\mathrm{r}$ value & $0.380^{*}$ & $0.399^{* *}$ & $0.404^{*}$ \\
\hline & $\mathrm{p}$ value & 0.029 & 0.008 & 0.010 \\
\hline \multirow{2}{*}{$\begin{array}{c}\text { Domain - } 6 \\
\text { (Participation) }\end{array}$} & rvalue & $0.483^{* *}$ & $0.507^{* *}$ & $0.531^{* *}$ \\
\hline & $\mathrm{p}$ value & 0.001 & 0.001 & 0.001 \\
\hline \multicolumn{5}{|c|}{$* p<0.05 \quad * * p<0.01$} \\
\hline
\end{tabular}

training and other healthy coping mechanisms which include positive cognitive behavioral strategies and the need for treatment and proper follow ups.

\section{Recommendations}

A protocol for psychosocial intervention can be developed and tested among patients having Obsessive compulsive disorder.

A longitudinal study can be conducted to check the effectiveness of psychosocial interventions on the severity level of illness and disability among patients having Obsessive compulsive disorder.

\section{Declaration of Interest}

The authors report no conflict of interest. The authors alone are responsible for the content and writing of this paper.

\section{Acknowledgements}

The authors extend their sincere thanks to all those who participated in the study. We express our thanks to Dr. Lawrence Prince and Dr. Aboumard Calra for granting permission for the use of tools Y- BOCS and WHO - DAS 2 respectively.

\section{References}

1. Torres AR, Lima MC. Epidemiology of obsessive-compulsive disorder: a review. Rev Bras Psiquiatr. 2005;27(3):237-42.

2. Khanna S, Gururaj G, Sriram TG. Epidemiology of the obsessive compulsive disorder in India. Presented at the first international obsessive compulsive disorder congress, Capri, March 9 -12. 1993.

3. World health Organization. The ICD-10 Classification of Mental and Behavioural Disorders: Clinical description of diagnostic guidelines, WHO. Delhi: AITBS publisher. 2007.
4. Shimshoni Y, Reuven O, Dar R, Hermesh H. Insight in obsessivecompulsive disorder: a comparative study of insight measures in an Israeli clinical sample. J Behav Ther Exp Psychiatry. 2011;42(3):38996. doi: 10.1016/j.jbtep.2011.02.011.

5. Tükel R, Polat A, Ozdemir O, Aksüt D, Türksoy N. Comorbid conditions in obsessive-compulsive disorder. Compr Psychiatry. 2002;43(3):2049.

6. Eisen JL, Mancebo MA, Pinto A, Coles ME, Pagano ME, Stout R, et al . Impact of obsessive-compulsive disorder on quality of life. Compr Psychiatry. 2006;47(4):270-5.

7. Masellis M, Rector NA, Richter MA. Quality of life in OCD: differential impact of obsessions, compulsions and depression comorbidity. Can J Psychiatry. 2003;48(2):72-7.

8. Mancebo MC, Greenberg B, Grant JE, Pinto A, Eisen JL, Dyck I, et al. Correlates of occupational disability in a clinical sample of obsessivecompulsive disorder. Compr Psychiatry. 2008;49(1):43-50.

9. Emmelkamp PM, de Haan E, Hoogduin CA. Marital adjustment and obsessive-compulsive disorder. Br J Psychiatry. 1990;156:55-60.

10. Staebler CR, Pollard CA, Merkel WT. Sexual history and quality of current relationships in patients with obsessive compulsive disorder: a comparison with two other psychiatric samples. J Sex Marital Ther. 1993;19(2):147-53.

11. Chakrabarti S, Kulhara P, Verma SK. The pattern of burden in families of neurotic patients. Soc Psychiatry Psychiatr Epidemiol. 1993;28(4):172-7.

12. The World Bank. World Development Report: Investing in health. New York: World bank and Oxford University Press 1993;213. ISBN : 9780-19-520890-0.

13. Murray C, Lopez A. The global burden of disease. A comprehensive assessment of mortality and disability from diseases, injuries and risk factors in 1990, and projected to 2020.vol. 1. Cambridge, MA: Harvard University Press 1996 URL : www.hsph.harvard.edu/organizations/ bdu/GBDbookorders.html

14. Storch EA, Rasmussen SA, Price LH, Larson MJ, Murphy TK, Goodman WK. Development and psychometric evaluation of the Yale-Brown Obsessive-Compulsive Scale--Second Edition. Psychol Assess. 2010;22(2):223-32. doi: 10.1037/a0018492.

15. Üstün TB, Kostanjsek N, Chatterji S, Rehm J. Measuring Health and Disability. Manual for WHO Disability Assessment Schedule-2. Accessed 7 July 2008. (World Health Organization can be obtained from .WHO Press, World Health Organization, 20 Avenue Appia, 1211 Geneva 27, Switzerland) URL : ( http://who.int/icidh/whodas/index. html )

16. Beşiroğlu L, CIlli AS, Aşkin R. The predictors of health care seeking behavior in obsessive-compulsive disorder. Compr Psychiatry. 2004;45(2):99-108.

17. Bobes J, González MP, Bascarán MT, Arango C, Sáiz PA, Bousoño M. Quality of life and disability in patients with obsessive-compulsive disorder. Eur Psychiatry. 2001; 16(4):239-45.

18. Huppert JD, Simpson HB, Nissenson KJ, Liebowitz MR, Foa EB. Quality of life and functional impairment in obsessive-compulsive disorder: a comparison of patients with and without comorbidity, patients in remission, and healthy controls. Depress Anxiety. 2009;26(1):39-45. doi: 10.1002/da.20506.

19. Chaudhury PK, Deka K, Chetia D. Disability associated with mental disorders. Indian J Psychiatry. 2006;48(2):95-101. doi: 10.4103/00195545.31597. 
20. Pinto A, Mancebo MC, Eisen JL, Pagano ME, Rasmussen SA. The Brown Longitudinal Obsessive Compulsive Study: clinical features and symptoms of the sample at intake. J Clin Psychiatry. 2006;67(5):70311.

21. Mohan I, Tandon R, Kalra H, Trivedi JK. Disability assessment in mental illnesses using Indian Disability Evaluation Assessment Scale (IDEAS). Indian J Med Res. 2005; 121(6):759-63.

22. Thomas JK, Suresh Kumar PN, Verma AN, Sinha VK, Andrade C. Psychosocial Dysfunction and Family Burden in Schizophrenia and Obsessive Compulsive Disorder. Indian J Psychiatry. 2004;46(3):23843.

23. Trivedi JK, Dhyani M, Goel D, Sharma S, Singh AP, Sinha PK, et al Neurocognitive dysfunction in patients with obsessive compulsive disorder. Afr J Psychiatry (Johannesbg). 2008;11(3):204-9.

24. De Geus F, Denys DA, Sitskoorn MM, Westenberg HG. Attention and cognition in patients with obsessive-compulsive disorder. Psychiatry Clin Neurosci. 2007;61(1):45-53

25. Moritz S, Kuelz AK, Jacobsen D, Kloss M, Fricke S. Severity of subjective cognitive impairment in patients with obsessive-compulsive disorder and depression. J Anxiety Disord. 2006;20(4):427-43.

26. Storch EA, Larson MJ, Muroff J, Caporino N, Geller D, Reid JM, et al. Predictors of functional impairment in pediatric obsessive-compulsive disorder. J Anxiety Disord. 2010;24(2):275-83. doi: 10.1016/j. janxdis.2009.12.004

27.Hou SY, Yen CF, Huang MF, Wang PW, Yeh YC. Quality of life and its correlates in patients with obsessive-compulsive disorder. Kaohsiung J Med Sci. 2010; 26(8):397-407. doi: 10.1016/S1607551X(10)70065-6.

28. Gururaj GP, Math SB, Reddy JY, Chandrashekar CR. Family burden, quality of life and disability in obsessive compulsive disorder: an Indian perspective. J Postgrad Med. 2008; 54(2):91-7.

29. Mathis MA, Alvarenga P, Funaro G, Torresan RC, Moraes I, Torres $\mathrm{AR}$, et al. Gender differences in obsessive-compulsive disorder: a literature review. Rev Bras Psiquiatr. 2011; 33(4):390-9.

30. Lochner C, Hemmings SMJ, Kinnear CJ, Moolman-Smook JC, Corfield VA, Knowles JA, et al . Gender in obsessive-compulsive disorder: clinical and genetic findings. Eur Neuropsychopharmacol. 2004; 14(2):105-13.

31. Khess CR, Akhtar S, Jagawat T, Das S, Srivastava A . Gender and psychopathology in obsessive compulsive disorder. Indian J Psychiatry. 1996; 38(3):166-71.

32.Vikas A, Avasthi A, Sharan P. Psychosocial impact of obsessivecompulsive disorder on patients and their caregivers: a comparative study with depressive disorder. Int J Soc Psychiatry. 2011; 57(1):4556. doi: 10.1177/0020764010347333.

33. Math SB, Janardhan Reddy YC. Issues in the pharmacological treatment of obsessive-compulsive disorder. Int J Clin Pract. 2007;61(7):118897.

34. Greist JH, Bandelow B, Hollander E, Marazziti D, Montgomery SA Nutt DJ, et al. WCA recommendations for the long-term treatment of obsessive-compulsive disorder in adults. CNS Spectr. 2003; 8(8 Suppl 1):7-16

35. Eisen JL, Pinto A, Mancebo MC, Dyck IR, Orlando ME, Rasmussen SA. A 2-year prospective follow-up study of the course of obsessivecompulsive disorder. J Clin Psychiatry. 2010; 71(8):1033-9. doi: 10.4088/JCP.08m04806blu.

36. Mancebo MC, Pinto A, Rasmussen SA, Eisen JL. Development of the Treatment Adherence Survey-patient version (TAS-P) for OCD. J Anxiety Disord. 2008; 22(1):32-43. 